\section{Comparison of Cytotoxicity and the Chemical Composition in Disporopsis pernyi and its Con- fused Variety}

\section{Kaijin Li, Tingting Feng, Wei Pan, Zengting Qian, Xiaohui Xia, Shengqin Ma, Yang Liu, Jian Gao* and Qisi Lin*}

Department of Pharmaceutical Analysis, School of Pharmacy, Xuzhou Medical University, Xuzhou, China

\begin{abstract}
The natural plant Disporopsis pernyi has been widely used as folk medicine for the treatment of chronic cough, cancer and other conditions in China. But we didn't know exactly what the active ingredients are. Disporopsis pernyi is often confused with Polygonatum odoratum and Panax japonicus. This study aimed to investigate the cytotoxic properties and chemical compositions of the three herbs. Eight pure compounds, which were identified as Stearic acid, Palmitic acid, $\beta$-Daucosterol, Luteolin, Rutin, Salicylic acid, Betulinic acid and Betulin were obtained and characterized from Disporopsis pernyi by column chromatography followed by IR, MS, $1 \mathrm{H}$ NMR and $13 \mathrm{C}$ NMR. The cytotoxic activities of the compounds and 4 fractions were tested against human breast cancer cell line MCF-7. The results suggested that the ethyl acetate fraction of Disporopsis pernyi had cytotoxic activity. Betulinic acid and Betulin contributed significantly to the cytotoxic activity of the extract. However, the extractions of Polygonatum odoratum and Panax japonicus did not have cytotoxic activity. Petroleum ether fractions from both Polygonatum odoratum and Panax japonicus were subjected to gas chromatography-mass spectrometry analysis, 9 and 16 species were identified, respectively. As a result, the three herbs were determined to be different from each other in terms of their volatile chemical constituents.
\end{abstract}

Keywords: Chemical compositions; Cytotoxic property; Disporopsis pernyi; Panax japonicus; Polygonatum odoratum

*Corresponding author: Qisi Lin, Department of Pharmaceutical Analysis School of Pharmacy, Xuzhou Medical University, Xuzhou, China, Tel: +86 516 8326 2111; E-mail: qslin074@126.com

Jian Gao, Department of Pharmaceutical Analysis, School of Pharmacy, Xuzhou Medical University, Xuzhou, China, Tel: +86 5168326 2111; E-mail: gaojian@ xzhmu.edu.cn

Citation: Li K, Feng T, Pan W, Qian Z, Xia X, et al. (2017) Comparison of Cytotoxicity and the Chemical Composition in Disporopsis pernyi and its Confused Variety. J Food Sci Nut 3: 024

Received: September 05, 2017; Accepted: October 02, 2017; Published: October 16, 2017

\section{Introduction}

An impressive number of modern drugs have been isolated from natural sources, especially, plants that have been used as a source of medicinal agents [1]. However, active ingredients of many medicinal plants have not been previously characterized. A Liliaceae is a large family of around 230 genera and 3500 species, characterized by showy flowers with six perianth segments, six stamens, and a superior ovary and usually producing bulbs or rhizomes [2]. Many Liliaceae plants are of high medical values, such as antifungal activity, anti tumour-promoter, insecticidal activity and anti-inflammatory [3-6].

Disporopsis pernyi (Hua) diels, which belongs to the genus Disporopsis of the family Liliaceae, is widespread in South Asia; however, it has not yet been successfully cultivated. This plant has been widely used for curing chronic cough and cancer in China [7]. The volatile compositions of Disporopsis pernyi have been previously characterized, but its effective components have seldom been reported [8].

Disporopsis pernyi is often confused with rhizoma polygonati odorati and Panax japonicus C.A. Mey. rhizoma polygonati is the dried rhizome of Polygonatum odoratum. The underground portion of Polygonatum odoratum has an appearance similar to that of Disporopsis pernyi. Hence, the two herbs are often confused with each other. Panax japonicus is commonly known as 'Zhujieshen' in China, although 'Zhujieshen' is also an alias of Disporopsis pernyi. The phenomenon of homonyms also creates confusion. Therefore, to exploit these species resources commercially, comprehensive research on their chemical constituents is necessary.

This study aimed to investigate the cytotoxic properties of the extracts and chemical compositions of the three herbs.

\section{Materials and Methods}

\section{Plant material}

Fresh Disporopsis pernyi were collected from an alpine site in August 2015. The site was located in the Guizhou province (longitude: $106^{\circ} 95^{\prime}-106^{\circ} 98^{\prime} \mathrm{E}$, latitude: $26^{\circ} 44^{\prime}-26^{\circ} 47^{\prime} \mathrm{N}$; altitude: $1200-1800 \mathrm{~m}$ ). Polygonatum odoratum (90226) and Panax japonicus (90149) were purchased from Pengxiang Pharmaceuticals Co., Ltd. The origins of them were showed in table 1 . The air-dried plant material was pulverized, screened through 40-mesh sieves, and stored in the refrigerator.

\section{Chemicals and reagents}

Methanol, petroleum ether, ethanol, ethyl acetate, anhydrous sodium sulphate and ferrous sulphate (analytical grade) were purchased from Tianjin Damao Chemical Reagent Co., Ltd. (Tianjin, China). Purified water was purchased from Hangzhou Wa ha ha Co. Ltd. (Hangzhou, China) n-Alkanes (9-35) were purchased from Aladdin Chemical Reagent Co. Ltd. (Shanghai, China). 
Citation: Li K, Feng T, Pan W, Qian Z, Xia X, et al. (2017) Comparison of Cytotoxicity and the Chemical Composition in Disporopsis pernyi and its Confused Variety. J Food Sci Nut 3: 024.

\begin{tabular}{|c|c|c|c|c|c|}
\hline Species & Alias & Family & Genus & Medicinal parts & Origin \\
\hline Disporopsis pernyi & Zhujieshen & Liliaceae & Disporopsis & Rhizome and root & Guizhou Province, China \\
\hline Polygonatum odoratum & Yuzhu & Liliaceae & Polygonatum & Rhizome & Liaoning Province, China \\
\hline Panax japonicus & Zhujieshen & Araliaceae & Panax & Anhuizome Province, China \\
\hline
\end{tabular}

\section{Extraction and isolation of Disporopsis pernyi}

Air-dried and finely powdered roots and rhizomes $(12.3 \mathrm{~kg})$ of Disporopsis pernyi were sequentially and exhaustively extracted with $70 \%$ ethanol, four times at $90^{\circ} \mathrm{C}$ for $2 \mathrm{~h}$, and the ethanol solutions were combined and concentrated in vacuo. The residue $(1.8 \mathrm{~kg})$ was suspended in $\mathrm{H}_{2} \mathrm{O}$ and sequentially extracted three times each with petroleum ether, chloroform, ethyl acetate and n-butanol to afford a petroleum ether fraction (PEF, 92g), a chloroform fraction (CF, 180g), an ethyl acetate fraction (EAF, 86g) and an n-butanol fraction (BF, 54g).

The PEF was subjected to silica-gel column chromatography (200-300 mesh, $1.2 \mathrm{~kg}$ ) by eluting with petroleum ether $(6.0 \mathrm{~L})$ and then with a gradient of petroleum ether-acetone by gradually increasing the polarity of the elution solvent system. The eluents were collected and monitored by TLC to yield 9 fractions (P1 to P9). P5 was isolated by silica gel and Sephadex LH-20 column chromatography to obtain compounds 1 (yield $0.2382 \mathrm{~g}, 0.0019 \%$ ) and 2 (yield $1.8514 \mathrm{~g}$, $0.0150 \%)$.

The CF was subjected to silica-gel column chromatography (200300 mesh, $1.2 \mathrm{~kg}$ ) by eluting with chloroform $(6.0 \mathrm{~L})$ and then with a gradient of chloroform-acetone by gradually increasing the polarity of the elution solvent system. The eluents were collected and monitored by TLC to yield 10 fractions ( $\mathrm{C} 1$ to $\mathrm{C} 10)$. $\mathrm{C} 10$ was isolated by silica gel and Sephadex LH-20 column chromatography to obtain compound 3 (yield $0.4681 \mathrm{~g}, 0.0038 \%$ ).

The EAF was subjected to silica-gel column chromatography (200-300 mesh, $1.2 \mathrm{~kg}$ ) by eluting with chloroform (6.0L) and then with a gradient of chloroform-methanol by gradually increasing the polarity of the elution solvent system. The eluents were collected and monitored by TLC to yield 8 fractions (E1 to E8). E3 was isolated by silica gel and Sephadex LH-20 column chromatography to obtain compound 4 (yield $0.1923 \mathrm{~g}, 0.0016 \%$ ). E6 was isolated by silica gel and Sephadex LH-20 column chromatography to obtain compounds 5 (yield $0.5251 \mathrm{~g}, 0.0043 \%$ ) and 6 (yield $0.3072 \mathrm{~g}, 0.0025 \%$ ).

The BF was subjected to macroporous resin D-101 (1.0kg) and then to a gradient of water-ethanol by gradually decreasing the polarity of the elution solvent system. The eluents were collected and monitored by TLC to yield 28 fractions (B1 to B28). B13 was isolated by silica gel and Sephadex LH-20 column chromatography to obtain a green substance, and the $\mathrm{pH}$ was adjusted to 4 by adding $\mathrm{HCl}$. Compound 7 (yield $0.3175 \mathrm{~g}, 0.0026 \%$ ) was then obtained by re crystallization. B20 was isolated by silica gel and Sephadex LH-20 column chromatography to obtain compound 8 (yield $0.1248 \mathrm{~g}, 0.0010 \%$ ).

\section{Identification of purity}

The purified compounds were identified by $1 \mathrm{H}$ NMR spectrometry, 13C NMR spectrometry and ESI-MS (micoOTOFQ, Bruker). 1H NMR spectra and 13C NMR spectra were recorded on a Bruker Avance DMX-600 spectrometer (Bruker Biospin GmbH, Germany) operating at $300 \mathrm{MHz}$ for $1 \mathrm{H}$ and $13 \mathrm{C}$. Chemical shifts were expressed in $\delta(\mathrm{ppm})$ downfield from TMS as an internal standard, and coupling constants were reported in hertz.

\section{Cytotoxicity assay}

Cell culture: MCF-7 human breast cancer cells were cultured in an RPMI 1640 nutritive medium supplemented with $10 \%$ Foetal Bovine Serum (FBS) at $37^{\circ} \mathrm{C}$ in a $5 \% \mathrm{CO}_{2}$ incubator. Fluorouracil was included as a reference substance.

Cell proliferation: tumor cells in the logarithmic growth phase were adjusted to $5 \times 10^{3}$ per well in a 96 well plate, and different concentrations of the tested samples were added after culturing for $24 \mathrm{~h}$. Then, $15 \mu \mathrm{L}$ MTT $(5 \mathrm{mg} / \mathrm{mL})$ was added to the 96 well plate and was cultured in a $\mathrm{CO}_{2}$ incubator for $48 \mathrm{~h}$. Stock solutions were made in $100 \%$ DMSO- $\mathrm{d}_{6}$ and were diluted in the medium to a final concentration of $0.2 \%(\mathrm{v} / \mathrm{v})$ DMSO- $\mathrm{d}_{6}$ before treatment. The cells were fixed in DMSO- $\mathrm{d}_{6}$ and stained with Acridine Orange (AO) and Ethidium Bromide (EB), and the cell morphology was observed using a fluorescence microscope.

The Absorbance (A) value was measured by a micro plate reader at a wavelength of $490 \mathrm{~nm}$. The cell inhibition rate was calculated according to the following formula: Inhibition ratio $(\%)=\left[\mathrm{A}_{490}(\mathrm{control})\right.$ - $\mathrm{A}_{490}($ test $\left.)\right] /\left[\mathrm{A}_{490}(\right.$ control $)-\mathrm{A}_{490}$ (blank) $] \times 100$.

\section{Preparation of the extracts}

According to the methods described in the literature, the air-dried powdered roots and rhizomes $(20 \mathrm{~g})$ of Polygonatum odoratum and Panax japonicus were extracted using a steam distillation apparatus [8]. The Essential Oils (EO) of Polygonatum odoratum (yield 0.158 $\pm 0.008 \mathrm{~g}, 0.79 \%$ ) and Panax japonicus (yield $0.241 \pm 0.014 \mathrm{~g}, 1.21 \%$ ) were stored at $4^{\circ} \mathrm{C}$.

According to the methods described in the literature, the air-dried powdered roots and rhizomes $(50 \mathrm{~g})$ of Polygonatum odoratum and Panax japonicus were successively extracted with $70 \%$ ethanol and ethyl acetate successively [8]. Ethyl Acetate Extracts (EAE) of the two herbs were evaporated to dryness under reduced pressure using a rotary evaporator. The EAE of Polygonatum odoratum (yield $3.591 \pm$ 0.141 g, $7.18 \%$ ) and Panax japonicus (yield $4.627 \pm 0.248 \mathrm{~g}, 9.25 \%$ ) were stored at $4^{\circ} \mathrm{C}$.

\section{Gas Chromatography-Mass Spectrometry (GC-MS)}

The EO of Polygonatum odoratum and Panax japonicus were injected into a SHIMADZU QP5050A series instrument for GC-MS analysis. An HP-5 MS capillary column $(30 \mathrm{~m} \times 0.25 \mathrm{~mm} ; 0.25 \mu \mathrm{m})$ was used for the separation. Helium was used as a carrier gas at a flow rate of $1.0 \mathrm{ml} / \mathrm{min}$. As described previously, essential oil analysis was performed by gas chromatography under the same conditions [8].

\section{Results and Discussion}

\section{Identification of purity}

Compound 1 was obtained as a white powder. ESI-MS $(\mathrm{m} / \mathrm{z})$ : 283[M-H]; The 1H-NMR spectrum $\left(\mathrm{CDC}_{13}, 300 \mathrm{MHz}\right): 11.023(1 \mathrm{H}$, s), $2.346(2 \mathrm{H}, \mathrm{t}, 7.5 \mathrm{~Hz}), 1.633(2 \mathrm{H}, \mathrm{t}, \mathrm{J}=7.5 \mathrm{~Hz}), 1.301(28 \mathrm{H}, \mathrm{s}), 0.880$ 
$(3 \mathrm{H}, \mathrm{t}, 6.5 \mathrm{~Hz})$. Thus, the structure of compound 1 was determined to be Stearic acid.

Compound 2 was obtained as a white crystalline substance. ESIMS (m/z): 255[M-H]; The 1H-NMR spectrum $\left(\mathrm{CDC}_{13}, 300 \mathrm{MHz}\right)$ $2.346(2 \mathrm{H}, \mathrm{t}, \mathrm{J}=7.5 \mathrm{~Hz}), 1.633(2 \mathrm{H}, \mathrm{m}), 1.257(24 \mathrm{H}, \mathrm{brs}), 0.880(3 \mathrm{H}$, $\mathrm{t}, \mathrm{J}=6.6 \mathrm{~Hz}$ ); IR spectrum showed absorptions at: 2954.5, 2916.7, $2848.5,1702.9,1470.9 \mathrm{~cm}^{-1}$. Thus, the structure of compound 2 was determined to be Palmitic acid.

Compound 3 was obtained as an odorless white powder: mp256$257^{\circ} \mathrm{C}$; The $1 \mathrm{H}-\mathrm{NMR}$ spectrum (DMSO, 300MHz): $0.812(3 \mathrm{H}, \mathrm{s})$, $0.822(3 \mathrm{H}, \mathrm{s}), 1.004(6 \mathrm{H}, \mathrm{s}), 1.059(3 \mathrm{H}, \mathrm{s}), 1.067(3 \mathrm{H}, \mathrm{s}), 1.788(3 \mathrm{H}, \mathrm{s})$, $3.530(1 \mathrm{H}, \mathrm{dd}, 11.4,4.2 \mathrm{~Hz}), 4.765(1 \mathrm{H}, \mathrm{s}), 4.942(1 \mathrm{H}, \mathrm{s}) ; 13 \mathrm{C}-\mathrm{NMR}$ spectrum: (DMSO, 300MHz), 150.258 (C-20), 109.947 (C-29), 78.156 (C-3), 56.659 (C-17), 51.002 (C-9), 49.819 (C-19), 47.838 (C-18), 42.880 (C-14), 41.154 (C-8), 39.543 (C-4), 38.689 (C-13), 37.557 (C-10), 34.870 (C-7), 32.929 (C-16), 28.675 (C-23), 28.334 (C-2), 21.232 (C-11), 19.505 (C-30), 16.362 (C-26); IR spectrum showed absorptions at $3381,2954,2871,1462$, and $1373 \mathrm{~cm}^{-1}$. Thus, the structure of compound 4 was determined to be Betulin.

Compound 4 was also obtained as an odorless white powder: 1H-NMR $\left(\mathrm{CDC}_{13}, 300 \mathrm{MHz}\right) \delta: 4.64(1 \mathrm{H}, \mathrm{s}), 4.51(1 \mathrm{H}, \mathrm{s}), 3.06(1 \mathrm{H}$, $\mathrm{m}), 1.68(3 \mathrm{H}, \mathrm{s}), 1.21(3 \mathrm{H}, \mathrm{s}), 0.98(3 \mathrm{H}, \mathrm{s}), 0.91(3 \mathrm{H}, \mathrm{s}), 0.80(3 \mathrm{H}, \mathrm{s})$, 0.70(3H, s); 13C-NMR (DMSO, 300MHz) $\delta: 14.4$ (C-27), 15.1 (C25), 15.9 (C-26), 16.0 (C-24), 18.9 (C-6), 19.9 (C-30), 20.7 (C-11), 25.2 (C-12), 28.2 (C-2), 28.8 (C-23), 29.9 (C-15), 29.9 (C-21), 32.7 (C-16), 33.8 (C-7), 36.5 (C-22), 37.3 (C-10), 38.0 (C-13), 39.3 (C-1), 40.4 (C-4), 40.9 (C-8), 42.9 (C-14), 48.4 (C-19), 48.6 (C-18), 49.2 (C9), 55.1 (C-5), 55.0 (C-17), 79.0 (C-3), 109.5 (C-29), 150.9 (C-20), 179.0 (C-28); IR spectrum showed absorptions at 3452, 3076, 2943 $28701688 \mathrm{~cm}^{-1}$. Thus, the structure of compound 4 was determined to be Betulinic acid.

Compound 5 was obtained as a white powder: 1H-NMR (DMSO, $300 \mathrm{MHz}) \delta: 5.31(1 \mathrm{H}, \mathrm{m}, \mathrm{H}-2), 4.87(1 \mathrm{H}, \mathrm{m}, \mathrm{H}-1$ ' $), 4.20-4.41(6 \mathrm{H}, \mathrm{m}$, H-2', 3', 4', 5', 6'), 0.64-1.00(18H, m, 6CH $), 2.88(1 \mathrm{H}, \mathrm{m}, \mathrm{H}-9), 2.49$, 1.93(2H, m, H-10), 13C-NMR (DMSO, 300MHz), $\delta: 140.502$ (C-1), 121.242 (C-2), 100.921 (C-1'), 78.576 (C-9), 76.831 (C-5'), 70.156 (C-4'), 73.516 (C-2'), 61.160 (C-6'), 56.227 (C-14), 55.483 (C-17), 50.638 (C-5), 49.667 (C-21), 45.199 (C-13), 41.905 (C-10), 40.423 (C-12), 38.754 (C-6), 38.365 (C-7), 36.877 (C-18), 36.261 (C-19), 35.526 (C-3), 31.467 (C-4), 29.294 (C-22), 29.056 (C-8), 28.775 (C20), 27.848 (C-15). TLC: Silica gel thin-layer chromatography was used and developed in three kinds of solvent systems; $\beta$-Daucosterol was used as a positive control and $10 \%$ sulphuric acid-ethanol (v/v) as a colour developing reagent; the TLC results showed that the compound and $\beta$-Daucosterol were similar. Thus, the structure of compound 5 was determined to be $\beta$-Daucosterol.

Compound 6 was obtained as a yellow powder: 1H-NMR (DMSO, $300 \mathrm{MHz}) \delta: 12.986(1 \mathrm{H}, \mathrm{s}), 10.793(\mathrm{brs}), 7.437(1 \mathrm{H}, \mathrm{s}), 7.417(1 \mathrm{H}$, $\mathrm{m}), 6.915(1 \mathrm{H}, \mathrm{d}, \mathrm{J}=9.0 \mathrm{~Hz}), 6.673(1 \mathrm{H}, \mathrm{s}), 6.463(1 \mathrm{H}, \mathrm{d}, \mathrm{J}=2.4 \mathrm{~Hz})$, $6.210(1 \mathrm{H}, \mathrm{d}, \mathrm{J}=2.4 \mathrm{~Hz}$ ); 13C-NMR (DMSO, 300MHz), $\delta: 163.979$ (C-2), 102.966 (C-3), 181.736 (C-4), 157.374 (C-5), 98.924 (C-6), 164.218 (C-7), 93.928 (C-8), 161.568 (C-9), 103.796 (C-10), 121.622 (C-1'), 113.476 (C-2'), 145.823 (C-3'), 149.773 (C-4'), 116.119 (C5'), 119.066 (C-6'). Thus, the structure of compound 6 was determined to be Luteolin.

Compound 7 was obtained as a green powder: EI-MS m/z:
609.0[M-H] $, \quad 633.1[\mathrm{M}+\mathrm{Na}]^{+}, \quad 611.1[\mathrm{M}+\mathrm{H}]^{+} ; \quad$ 1H-NMR $(\mathrm{MeOD}$ $300 \mathrm{MHz}) \delta: 6.203(1 \mathrm{H}, \mathrm{S}), 6.389(1 \mathrm{H}, \mathrm{S}), 6.874(1 \mathrm{H}, \mathrm{d}, \mathrm{J}=8.4 \mathrm{~Hz})$, $7.641(2 \mathrm{H}, \mathrm{dd}, \mathrm{J}=6.8 \mathrm{~Hz})$; 13C-NMR (MeOD, 300MHz) $\delta: 158.467$ (C-2), 135.627 (C-3), 179.381 (C-4), 162.925 (C-9), 99.939 (C-6), 165.973 (C-7), 94.866 (C-8), 159.316 (C-5), 105.612 (C-10), 123.109 (C-1'), 116.048 (C-2'), 149.774 (C-4'), 117.700 (C-5'), 123.109 (C6'), 102.399 (C-1”), 75.715 (C-5”), 77.186 (C-3”), 71.377 (C-4”), 68.546 (C-6"), 104.730 (C-1"'), 72.079 (C-2"'), 72.232 (C-3"'), 73.929 (C-4"'), 69.691 (C-5"'), 17.870 (C-6"'); IR spectrum showed absorptions at $3421.5,2923.6,2853.3,1656.2,1602.0,1503.5 \mathrm{~cm}^{-1}$. Thus, the structure of compound 7 was determined to be Rutin.

Compound 8 was obtained as a white crystalline substance. 1H-NMR $\left(\mathrm{CDC}_{13}, 300 \mathrm{MHz}\right) \delta: 7.936(1 \mathrm{H}, \mathrm{dd}, \mathrm{J}=7.8,0.9 \mathrm{~Hz}, 3-\mathrm{H})$, 7. $528(1 \mathrm{H}, \mathrm{ddd}, \mathrm{J}=7.2,7.2,0.9 \mathrm{~Hz}, 5-\mathrm{H}), 7.016(1 \mathrm{H}, \mathrm{dd}, \mathrm{J}=8.4,0.9$ $\mathrm{Hz}), 6.942(1 \mathrm{H}, \mathrm{ddd}, \mathrm{J}=7.2,7.2,1.2 \mathrm{~Hz})$; IR spectrum showed absorptions at 3237.6, 3008.5, 2857.6, 2594.4, 1657.5, 1611.8, 1030.4, $760.1,698.6 \mathrm{~cm}^{-1}$. Thus, the structure of compound 8 was determined to be Salicylic acid (Table 2).

\section{Evaluation of cytotoxicity}

We initially tested the effect of the 4 fractions (PEF, CF, EAF and $\mathrm{BF}$ ) of the three herbs on the growth of MCF-7 human breast cancer cells for $24 \mathrm{~h}$ by adding fresh compounds. All fractions of Polygonatum odoratum and Panax japonicus did not show Cytotoxicity. The EAF of Disporopsis pernyi significantly reduced the cell number compared to the vehicle alone $\left(2 \%\right.$ DMSO- $\left.\mathrm{d}_{6}\right)$. The effective concentration of the samples is shown in figure 1 , and there was a $48 \%$ reduction in cell number at $315.8 \mu \mathrm{g} / \mathrm{ml}$. As showed in figure 2 , the observed change in the color of the cell from green to yellow or red fluorescence appeared to be due to increased membrane permeability and apoptosis. While its counterfeits and substitutes, Polygonatum odoratum and Panax japonicus, do not show cytotoxicity against MCF-7 cells in this test.

Betulinic acid and Betulin have been reported to have activity against various pathogenic microbes, including anti-HIV activity and inducing apoptosis [9-11]. The Cytotoxicity of EAF against MCF-7 cells might be related to Betulinic acid and Betulin $[12,13]$. The other fractions did not show significant activity against MCF-7 cells, so did the fractions of Polygonatum odoratum and Panax japonicus.

\section{Chemical compositions of the EO}

The chemical compositions of the EO from Disporopsis pernyi have been previously reported by our research group [8]. In the present study, the chemical compositions of the EO from Polygonatum odoratum and Panax japonicus were detected using the same conditions and methods. Figure 3 shows the Total Ion Chromatograms (TIC) of the EO. The GC-MS analysis of these two herbs resulted in the identification of 9 and 14 constituents, representing $61.25 \%$ and $92.70 \%$ of the volatile components, respectively (Table 3 and 4 ). Twelve volatile compounds from Disporopsis pernyi were identified according to the literature [8]. Pentadecenoic acid methyl ester, hexadecanoic acid methyl ester, n-hexadecanoic acid, and 9, 12-octadecadienoic acid were the major volatile components identified in Disporopsis pernyi. The comparison of the main volatile components of the three herbs showed remarkable differences. 
Citation: Li K, Feng T, Pan W, Qian Z, Xia X, et al. (2017) Comparison of Cytotoxicity and the Chemical Composition in Disporopsis pernyi and its Confused Variety. J Food Sci Nut 3: 024.

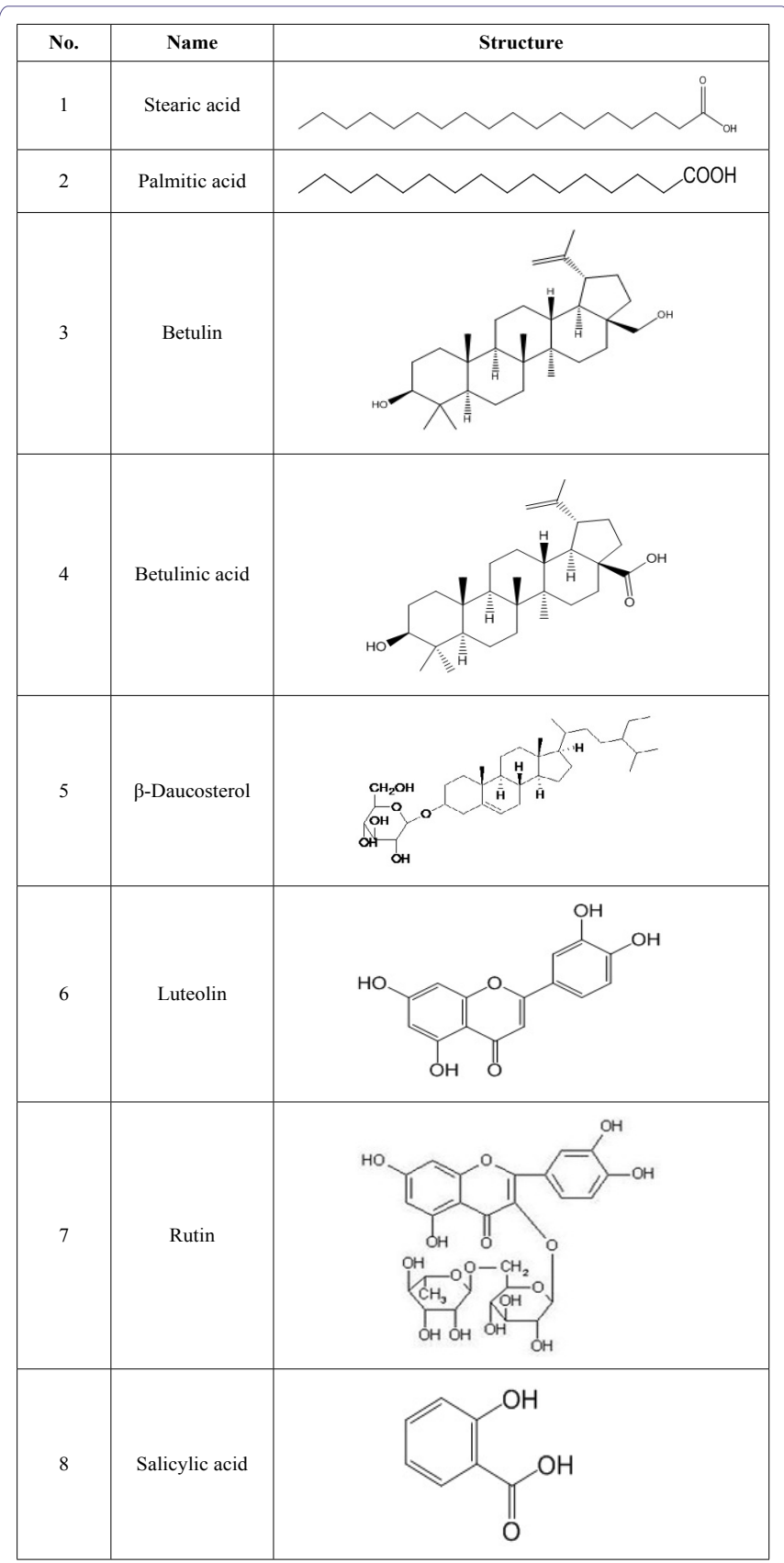

Table 2: The compounds isolated from Disporopsis pernyi (Hua) Diels.

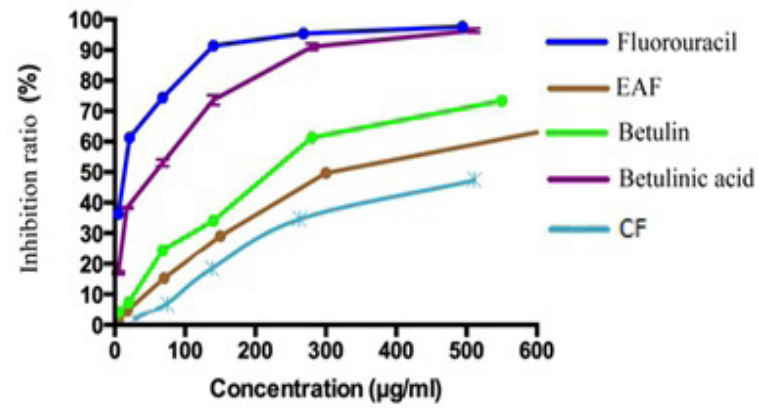

Figure 1: The inhibitory effect of different effective parts on MCF-7 cells.
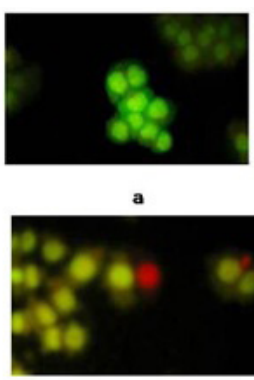

c

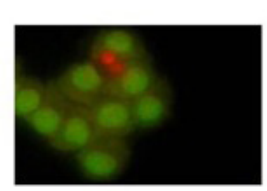

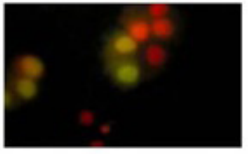

b

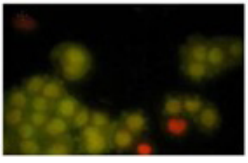

d
Figure 2: The morphology of MCF-7 cells under the effect of effective parts. a) blank control; b) $165.2 \mu \mathrm{g} / \mathrm{mL}$ Betulinic acid; c) $143.5 \mu \mathrm{g} / \mathrm{mL}$ Betulin; d) $315.8 \mu \mathrm{g} / \mathrm{mL}$ EAF e) $298.4 \mu \mathrm{g} / \mathrm{mL} \mathrm{CF}$.

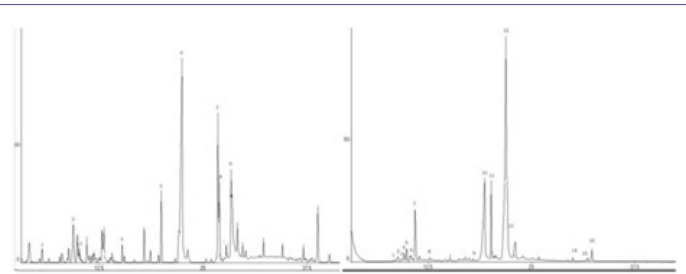

A

Figure 3: TIC of the EO a) Polygonatum odoratum, b) Panax japonicas.

\begin{tabular}{|c|c|c|c|c|c|}
\hline No. & Compounds $^{\mathrm{a}}$ & Groups & $\begin{array}{c}\text { Method of } \\
\text { Identification }\end{array}$ & $\mathbf{R} \mathbf{I}^{\mathbf{c}}$ & RA\% \\
\hline 1 & D-limonene & Alkanes, Alkenes & MS, RI & 983.7 & trace \\
\hline 2 & Undecane & Alkanes, Alkenes & MS, RI, S & 1102.2 & 2.24 \\
\hline 3 & Longifolene & Alkanes, Alkenes & MS, RI & 1448.4 & 4.27 \\
\hline 4 & Pentadecanoic acid & $\begin{array}{l}\text { Fatty acids, Ali- } \\
\text { phatic esters }\end{array}$ & MS, RI & 1861.2 & 1.19 \\
\hline 5 & $\begin{array}{l}\text { n-Hexadecanoic acid } \\
\text { methyl ester }\end{array}$ & $\begin{array}{l}\text { Fatty acids, Ali- } \\
\text { phatic esters }\end{array}$ & MS, RI, S & 1922.6 & 6.2 \\
\hline 6 & n-Hexadecanoic acid & $\begin{array}{l}\text { Fatty acids, Ali- } \\
\text { phatic esters }\end{array}$ & MS, RI, S & 1999.2 & 31.14 \\
\hline 7 & $\begin{array}{l}\text { 9-Octadecenoic acid, } \\
\text { methyl ester }\end{array}$ & $\begin{array}{l}\text { Fatty acids, Ali- } \\
\text { phatic esters }\end{array}$ & MS, RI & 2106.9 & 9.7 \\
\hline 8 & Linoleic acid & $\begin{array}{l}\text { Fatty acids, Ali- } \\
\text { phatic esters }\end{array}$ & MS, RI, S & 2158.8 & 2.89 \\
\hline 9 & $\begin{array}{c}\text { Linoleic acid ethy- } \\
\text { lester }\end{array}$ & $\begin{array}{l}\text { Fatty acids, Ali- } \\
\text { phatic esters }\end{array}$ & MS, RI & 2194.8 & 10.62 \\
\hline & & & \multicolumn{2}{|c|}{ Total 9 compounds } & 61.25 \\
\hline & & & \multicolumn{2}{|c|}{ Alcohols } & 0.00 \\
\hline & & & \multicolumn{2}{|c|}{$\begin{array}{c}\text { Fatty acids and Aliphatic } \\
\text { esters }\end{array}$} & 54.74 \\
\hline & & & \multicolumn{2}{|c|}{ Alkanes, Alkenes } & 6.51 \\
\hline
\end{tabular}

Table 3: Average content (in percentage) of volatile components from Polygonatum odoratum.

a. Compounds are listed in order of elution from a HP-5MS column

b. Method of Identification: MS, compared with NIST107 Mass Spectral Database; $\mathrm{RI}$, agree with retention index of literatures; $\mathrm{S}$, compared with retention indexes and mass spectra of the authentic chemicals

c. RI (Retention Index) was calculated relative to $\mathrm{C}_{9}-\mathrm{C}_{34}$ n-alkanes on a HP-5MS column 
Citation: Li K, Feng T, Pan W, Qian Z, Xia X, et al. (2017) Comparison of Cytotoxicity and the Chemical Composition in Disporopsis pernyi and its Confused Variety. J Food Sci Nut 3: 024.

\begin{tabular}{|c|c|c|c|c|c|}
\hline No. & Compounds $^{\mathrm{a}}$ & Groups & $\begin{array}{c}\text { Method of } \\
\text { identification }\end{array}$ & $\mathbf{R} \mathbf{I}^{\mathrm{c}}$ & RA\% \\
\hline 1 & Hexanoic acid & $\begin{array}{c}\text { Fatty acids, } \\
\text { Aliphatic esters }\end{array}$ & MS, RI, S & 993.7 & Trace \\
\hline 2 & $\Gamma$-element & Alkanes, Alkenes & MS, RI & 1336.3 & 0.63 \\
\hline 3 & $\alpha$-copaene & Alkanes, Alkenes & MS, RI & 1379.6 & Trace \\
\hline 4 & Aromadendrene & Alkanes, Alkenes & MS, RI & 1407.8 & Trace \\
\hline 5 & $\alpha$-Trans-bergamotene & Alkanes, Alkenes & MS, RI & 1439.3 & Trace \\
\hline 6 & (E)- $\beta$-farnesene & Alkanes, Alkenes & MS, RI & 1463.7 & Trace \\
\hline 7 & (-)-Spathulenol & Alcohols & MS, RI & 1564.8 & 6.22 \\
\hline 8 & Epiglobulol & Alcohols & MS, RI & 1615.7 & Trace \\
\hline 9 & $\begin{array}{l}\text { Hexadecanoic acid, } \\
\text { Methyl ester }\end{array}$ & $\begin{array}{c}\text { Fatty acids, } \\
\text { Aliphatic esters }\end{array}$ & MS, RI, S & 1923.7 & Trace \\
\hline 10 & Palmitic acid & $\begin{array}{c}\text { Fatty acids, } \\
\text { Aliphatic esters }\end{array}$ & MS, RI, S & 1996 & 18.77 \\
\hline 11 & (Z)-Falcarinol & Alcohols & MS, RI & 2036.8 & 7.3 \\
\hline 12 & $\begin{array}{l}\text { Linoleic acid ethyl } \\
\text { ester }\end{array}$ & $\begin{array}{c}\text { Fatty acids, } \\
\text { Aliphatic esters }\end{array}$ & MS, RI, S & 2168.8 & 50.82 \\
\hline 13 & $\begin{array}{l}\text { (Z,Z)-3,13-Octadeca- } \\
\text { dien-1-ol }\end{array}$ & Alcohols & MS, RI & 2339.3 & 6.47 \\
\hline 14 & n-octacosane & Alkanes, Alkenes & MS, RI, S & 2803.1 & Trace \\
\hline 15 & Docosanoic acid & $\begin{array}{l}\text { Fatty acids, } \\
\text { Aliphatic esters }\end{array}$ & MS, RI, S & 2884.5 & 0.75 \\
\hline 16 & Nonacosane & Alkanes, Alkenes & MS, RI, S & 2904 & 1.74 \\
\hline & & & \multicolumn{2}{|c|}{ Total 16 compounds } & 92.70 \\
\hline & & & \multicolumn{2}{|c|}{ Alcohols } & 0.00 \\
\hline & & & \multicolumn{2}{|c|}{$\begin{array}{c}\text { Fatty acids and Aliphatic } \\
\text { esters }\end{array}$} & 54.74 \\
\hline & & & \multicolumn{2}{|c|}{ Alkanes, Alkenes } & 6.51 \\
\hline
\end{tabular}

\section{Conclusion}

Eight pure compounds, which were identified as Stearic acid, Palmitic acid, $\beta$-Daucosterol, Luteolin, Rutin, Salicylic acid, Betulinic acid and Betulin, were obtained and characterized from Disporopsis pernyi. Some of the compounds, including Stearic acid, Luteolin, Rutin, Salicylic acid, Betulinic acid and Betulin, which we found in Disporopsis pernyi, have not been reported in Polygonatum odoratum and Panax japonicus.

The EAF from Disporopsis pernyi conspicuously restrained the growth of MCF-7 human breast cancer cells. Betulin and Betulinic acid have been used against a variety of cell lines, such as malignant brain tumor, primitive neuro ectodermal tumor [12], human chronic myelogenous leukemia, and against most of the prevalent human cancer types, such as cervical, prostate, breast, lung or colorectal cancer [13]. Betulinic acid and Betulin are plant products found in the genera Betulla, Diospiros, Paeonia, Syzigium or Ziziphus [14]. Betulinic acid and Betulin belong to triterpenoids, which represent a large group of plant products with a broad variety of biological activity [15-17]. The results suggested that the two triterpenes, Betulin and Betulinic acid, contributed significantly to the cytotoxicity of Disporopsis pernyi against MCF-7cells.

Although Disporopsis pernyi and its confused varieties share some similar compositions of EO, such as palmitic acid 9, 12-Octadecadienoic acid and Linolenic acid, their volatile constituents are different from each other.

\section{Acknowledgment}

This project was supported by National Natural Science Foun- dation of China (NSFC No. 21708033) and Jiangsu Natural Science Foundation (BK20140225). The authors declare that there is no conflict of interest regarding the publication of this paper.

\section{References}

1. Esiyok D, Otles S, Akcicek E (2004) Herbs as food source in Turkey. Asian Pac J Cancer Prev 5: 334-339.

2. Duarte MCT, Figueira GM, Sartoratto A, Rehder VL, Delarmelina C (2005) Anti-Candida activity of Brazilian medicinal plants. J Ethnopharmacol 97: 305-311.

3. Park HJ, Lee JY, Moon SS, Hwang BK (2003) Isolation and anti-oomycete activity of nyasol from Anemarrhena asphodeloides rhizomes. Phytochemistry 64: 997-1001.

4. Nakamura O, Mimaki Y, Nishino H, Sashida Y (1994) Steroidal saponins from the bulbs of Lilium speciosum x L. nobilissimum 'Star Gazer' and their antitumour-promoter activity. Phytochemistry 36: 463-467.

5. Qisi L, Miao W, Jinghua L, Wanping S, Hui W, et al. (2014) Analysis of Fatty Acids, Aliphatic Esters, and In Vitro Studies of Antioxidant and Antimicrobial Activities for Recineckea carnea and Tupistra chinensis from the Guizhou Province. J Med Food 17: 236-243.

6. Li N, Zhang JY, Zeng KW, Zhang L, Che YY, et al. (2012) Anti-inflammatory homoisoflavonoids from the tuberous roots of Ophiopogon japonicus. Fitoterapia 83: 1042-1045.

7. Nguyen AT, Fontaine J, Malonne H, Duez P (2006) Homoisoflavanones from Disporopsis aspera. Phytochemistry 67: 2159-2163.

8. Lin Q, Zhang L, Yang D, Chunjie Z (2014) Contribution of phenolics and essential oils to the antioxidant and antimicrobial properties of Disporopsis pernyi (Hua) Diels. J Med Food 17: 714-722.

9. Cichewicz RH, Kouzi SA (2004) Chemistry, biological activity, and chemotherapeutic potential of betulinic acid for the prevention and treatment of cancer and HIV infection. Med Res Rev 24: 90-114.

10. Kuo RY, Qian K, Susan L, Morris-Natschke, Lee KH (2009) Plant-derived triterpenoids and analogues as antitumor and anti-HIV agents. Nat Prod Rep 26: 1321-1344.

11. KueteV, Wabo GF, Ngamenib B, Mbaveng AT, Metunob R, et al. (2007) Antimicrobial activity of the methanolic extract, fractions and compounds from the stem bark of Irvingia gabonensis (Ixonanthaceae). J Ethnopharmacol 114: 54-60.

12. Rzeski W, Stepulak A, Szymanski M, Sifringer M, Kaczor J, et al. (2006) Betulinic acid decreases expression of bcl-2 and cyclin D1, inhibits proliferation, migration and induces apoptosis in cancer cells. Naunyn-Schmiedeberg's Archives of Pharmacolog 374: 11-20.

13. Yogeeswari P, Sriram D (2005) Betulinic acid and its derivatives: a review on their biological properties. Curr Med Chem 12: 657-666.

14. Zuco V, Supino R, Righetti SC, Cleris L, Marchesi E, et al. (2002) Selective cytotoxicity of betulinic acid on tumor cell lines, but not on normal cells. Cancer Lett 175: 17-25.

15. You YJ, Kim Y, Nam NH, Ahn BZ (2003) Synthesis and cytotoxic activity of A-ring modified betulinic acid derivatives. Bioorg Med Chem Lett 13: 3137-3140.

16. Horiuchi K, Shiot S, Hatno T, Yoshida T, Kuroda T, et al. (2007) Antimicrobial activity of oleanolic acid from Salvia officinalis and related compounds on vancomycin-resistant enterococci (VRE). Biol Pharm Bull 30: 1147-1149.

17. Šarek J, Kvasnica M, Vlk M, Urban M, Dzubák P, et al. (2011) The potential of triterpenoids in the treatment of melanoma. In Tech. 